\title{
Front Matter: Volume 8730
}

, "Front Matter: Volume 8730," Proc. SPIE 8730, Flexible Electronics, 873001 (11 June 2013); doi: 10.1117/12.2031989

SPIE Event: SPIE Defense, Security, and Sensing, 2013, Baltimore, Maryland, United States 


\title{
PROCEEDINGS OF SPIE
}

\section{Flexible Electronics}

\author{
David R. Allee \\ Eric W. Forsythe \\ Editors
}

1-2 May 2013

Baltimore, Maryland, United States

Sponsored and Published by

SPIE 
The papers included in this volume were part of the technical conference cited on the cover and title page. Papers were selected and subject to review by the editors and conference program committee. Some conference presentations may not be available for publication. The papers published in these proceedings reflect the work and thoughts of the authors and are published herein as submitted. The publisher is not responsible for the validity of the information or for any outcomes resulting from reliance thereon.

Please use the following format to cite material from this book:

Author(s), "Title of Paper," in Flexible Electronics, edited by David R. Allee, Eric W. Forsythe, Proceedings of SPIE Vol. 8730 (SPIE, Bellingham, WA, 2013) Article CID Number.

ISSN: 0277-786X

ISBN: 9780819498106

Published by

SPIE

P.O. Box 10, Bellingham, Washington 98227-0010 USA

Telephone +1 3606763290 (Pacific Time) · Fax +1 3606471445

SPIE.org

Copyright (C) 2013, Society of Photo-Optical Instrumentation Engineers.

Copying of material in this book for internal or personal use, or for the internal or personal use of specific clients, beyond the fair use provisions granted by the U.S. Copyright Law is authorized by SPIE subject to payment of copying fees. The Transactional Reporting Service base fee for this volume is $\$ 18.00$ per article (or portion thereof), which should be paid directly to the Copyright Clearance Center (CCC), 222 Rosewood Drive, Danvers, MA 01923. Payment may also be made electronically through CCC Online at copyright.com. Other copying for republication, resale, advertising or promotion, or any form of systematic or multiple reproduction of any material in this book is prohibited except with permission in writing from the publisher. The CCC fee code is 0277-786X/13/\$18.00.

Printed in the United States of America.

Publication of record for individual papers is online in the SPIE Digital Library.

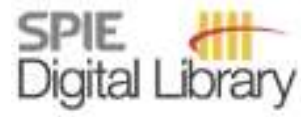

SPIEDigitalLibrary.org

Paper Numbering: Proceedings of SPIE follow an e-First publication model, with papers published first online and then in print and on CD-ROM. Papers are published as they are submitted and meet publication criteria. A unique, consistent, permanent citation identifier (CID) number is assigned to each article at the time of the first publication. Utilization of CIDs allows articles to be fully citable as soon as they are published online, and connects the same identifier to all online, print, and electronic versions of the publication. SPIE uses a six-digit CID article numbering system in which:

- The first four digits correspond to the SPIE volume number.

- The last two digits indicate publication order within the volume using a Base 36 numbering

system employing both numerals and letters. These two-number sets start with 00, 01, 02, 03, 04,

$05,06,07,08,09,0 A, 0 B \ldots 0 Z$, followed by 10-1Z, 20-2Z, etc.

The CID Number appears on each page of the manuscript. The complete citation is used on the first page, and an abbreviated version on subsequent pages. Numbers in the index correspond to the last two digits of the six-digit CID Number. 


\section{Contents}

$\checkmark \quad$ Conference Committee

\section{SESSION 1 FLEXIBLE ELECTRONICS I}

873003 High-performance logic circuits using solution-based, low-temperature semiconductors for flexible electronics [8730-2]

I. Mejia, A. L. Salas-Villasenor, J. W. Murphy, The Univ. of Texas at Dallas (United States);

G. R. Kunnen, Arizona State Univ. (United States); K. D. Cantley, The Univ. of Texas at Dallas (United States); D. R. Allee, Arizona State Univ. (United States); B. E. Gnade,

M. A. Quevedo-Lopez, The Univ. of Texas at Dallas (United States)

873004 Flexible packaging and integration of CMOS IC with elastomeric microfluidics [8730-3]

B. Zhang, Q. Dong, C. E. Korman, Z. Li, M. E. Zaghloul, The George Washington Univ. (United States)

\section{SESSION 2 FLEXIBLE ELECTRONICS II}

873009 Flexible microstrip antennas [8730-9]

C. A. Cano Barrera, Univ. EAFIT (Colombia)

\section{SESSION 3 FLEXIBLE ELECTRONICS III}

8730 OC Flexible amorphous silicon PIN diode $x$-ray detectors [8730-13]

M. Marrs, E. Bawolek, J. T. Smith, G. B. Raupp, Arizona State Univ. (United States); D. Morton, U.S. Army Research Lab. (United States)

\section{SESSION 4 FLEXIBLE ELECTRONICS IV}

$8730 \mathrm{OF} \quad$ Flexible digital $x$-ray technology for far-forward remote diagnostic and conformal x-ray imaging applications [8730-16]

J. Smith, M. Marrs, M. Strnad, Arizona State Univ. (United States); R. B. Apte, J. Bert, Palo Alto Research Ctr., Inc. (United States); D. Allee, N. Colaneri, Arizona State Univ. (United States); E. Forsythe, D. Morton, U.S. Army Research Lab. (United States)

8730 OG Sol gel ZnO films doped with Mg and Li evaluated for charged particle detectors [8730-17] J. W. Murphy, A. Eddy, The Univ. of Texas at Dallas (United States); G. R. Kunnen, Arizona State Univ. (United States); I. Mejia, K. D. Cantley, The Univ. of Texas at Dallas (United States); D. R. Allee, Arizona State Univ. (United States); M. A. Quevedo-Lopez, B. E. Gnade, The Univ. of Texas at Dallas (United States) 
$8730 \mathrm{OH}$ Development of a testbed for flexible a-Si:H photodiode sensing arrays [8730-18]

A. Dominguez, G. Kunnen, M. Vetrano, J. Smith, M. Marrs, D. R. Allee, Arizona State Univ. (United States)

Author Index

Proc. of SPIE Vol. $8730873001-4$

Downloaded From: https://www.spiedigitallibrary.org/conference-proceedings-of-spie on 26 Apr 2023 Terms of Use: https://www.spiedigitallibrary.org/terms-of-use 


\title{
Conference Committee
}

\author{
Symposium Chair
}

Kenneth R. Israel, Major General (USAF Retired) (United States)

Symposium Cochair

David A. Whelan, Boeing Defense, Space, and Security (United States)

Conference Chairs

David R. Allee, Arizona State University (United States)

Eric W. Forsythe, U.S. Army Research Laboratory (United States)

Conference Program Committee

Nick Colaneri, Arizona State University (United States)

Khershed P. Cooper, U.S. Naval Research Laboratory (United States)

Pat Edmiston, Raytheon Network Centric Systems (United States)

Bruce E. Gnade, The University of Texas at Dallas (United States)

Joshua A. Hagen, Air Force Research Laboratory (United States)

David C. Morton, U.S. Army Research Laboratory (United States)

Stephen M. Phillips, Arizona State University (United States)

Manuel Quevedo-Lopez, The University of Texas at Dallas (United States)

Robert H. Reuss, Defense Advanced Research Projects Agency (United States)

Jennifer C. Ricklin, Air Force Research Laboratory (United States)

\section{Session Chairs}

1 Flexible Electronics I

Robert H. Reuss, Defense Advanced Research Projects Agency (United States)

2 Flexible Electronics II

Robert H. Reuss, Defense Advanced Research Projects Agency (United States)

3 Flexible Electronics III

Robert H. Reuss, Defense Advanced Research Projects Agency (United States) 
$4 \quad$ Flexible Electronics IV

Kurtis Cantley, The University of Texas at Dallas (United States)

5 Flexible and Wearable Electronics for Defense Applications: Joint Session with Conferences 8725 and 8730

Muhammad M. Hussain, King Abdullah University of Science and Technology (Saudi Arabia)

Ali Javey, University of California, Berkeley (United States) 